\section{Economic Minerals}

THe third number of Sands, Clays and Minerals, a new quarterly magazine devoted to economic minerals, contains a series of articles covering a varied and attractive field. Particularly noteworthy is a paper on British coals by Mr. A. L. Curtis in which a wealth of interesting information on the origin, composition and classification of coals and related materials, such as graphite, jet and peat, is gathered together. This is effectively illustrated by a beautifully produced coloured plate showing typical handspecimens of fourteen of the materials dealt with. Other articles describe raw materials such as sands, tripoli powder, and sapphire (with two plates of rough and cut stones); research methods involving the application of ultra-violet light, elutriation, magnetism and heavy liquids; the mining of china clay, the properties of refractory cements, the decay and restoration of building stones, and the sources and uses of tantalum and niobium. The magazine is likely to be of great service to technical and com. mercial men who are interested in mineral products but may not have the time or opportunity to follow the more specialised literature. It is published by Mr. A. L. Curtis, Westmoor Laboratory, Chatteris, the annual subscription being $5 s$.

\section{Researches on Cacao}

Tae first annual report on cacao research in 1931 carried out by the Imperial College of Tropical Agriculture, Trinidad, has just been published. Founded in 1922, the first years of the life of the College were necessarily occupied in academic duties, and although cacao was included in the scheme for long-range research work in 1927, it was not until 1930, when contributions from the cacao-producing Colonies and some of the manufacturers in Great Britain allowed of the purchase of a small estate and the recruitment of three special research officers, that any large development in this side of the work took place. The report deals with the results of the first year's investigations and it is a tribute to the College that so much fundamental information should have been gained in such a short time. On the botanical side, the problem has been approached from three main aspects, namely, propagation studies, genetical survey and studies of fruitfulness, and it is proposed to continue the work on similar lines in the future. The chemical and ecological section has begun an environmental study of the cacao tree and has carried out a soil survey of the Gran Couva district with a view of determining how soil types and environment affect productivity. Both growers and manufacturers alike should profit from the improved yield and quality in the crops, which there is every hope will result from these investigations. The report, price ls., may be obtained on application to the Editor of Tropical Agriculture, Imperial College of Tropical Agriculture, Trinidad, British West Indies.

\section{Deaf and Dumb in England and Wales}

THE National Institute for the Deaf has issued a memorandum commenting upon a report by the late Dr. Eichholz to the Minister of Health and the
President of the Board of Education on "A Study of the Deaf in England and Wales, 1930 to 1932". It is considered that the proposals contained in the report are inadequate to meet the needs of the deaf and dumb and of those who become deaf through disease or accident. Disappointment is expressed with regard to some of the proposals, and suggestions are made which it is considered would better the position, though it is realised that it may be impos. sible at present to incur fresh expenditures upon the work necessary to ensure the well-being of these classes.

\section{Bibliography of Earthquakes}

The Dominion Observatory at Ottawa has continued its useful work by publishing a list of one hundred memoirs on earthquakes received during the third quarter of 1932 . With very few exceptions, the memoirs belong to the last two years. All the principal countries in which earthquakes are studied are well and uniformly represented, a result that is no doubt due to the appointment of collaborators in Italy, France, England, Canada, Japan and Germany, as well as in various parts of the United States.

\section{New Air Speed Record}

Warrant Officer Francesco Agello, of the Italian Air Force, set up a new air speed record on April 10, when he attained an average speed of $423 \cdot 76$ miles an hour. Agello was flying a MacchiCastoldi 72 seaplane at Desenzano, Lake Garda, and it is stated that on one run he reached a speed of more than 430 miles an hour. The machine was one of those originally intended for the Schneider trophy race of 1931. The previous record, 408 miles an hour, was set up on September 29, 1931, in a Vickers-Supermarine $S 6 B$ seaplane flown by FlightLieut. G. H. Stainforth.

\section{New Director of the U.S. Bureau of Standards}

IT is announced by Science Service, Washington, D.C., that Dr. Lyman J. Briggs has been appointed director of the U.S. Bureau of Standards, in succession to Dr. G. K. Burgess, who died on July 2, 1932. Dr. Briggs has been chief of the Division of Mechanics and Sound of the Bureau since 1920. He has carried out much research on aerodynamics, gyroscopic stabilisation and properties of liquids. He is the co-inventor, with Dr. Paul R. Heyl (also of the Bureau of Standards), of the earth inductor compass that is now widely used in aircraft. For this invention, Drs. Briggs and Heyl shared the Magellan fund and medal, awarded by the American Philosophical Society for "the best discovery or most useful invention relating to navigation, astronomy, or natural philosophy".

\section{Sectional Meeting of World Power Conference}

THIs year the World Power Conference sectional meeting will be held in Scandinavia, on June 26July 8. Everyone interested in the energy problems of large industrial undertakings is cordially invited to take part. The Conference opens at Copenhagen 
on June 26. The members next proceed to Stockholm by special sleeping-car trains, where the opening address will be given by the Crown Prince of Sweden. A number of very attractive tours has been arranged, including one to Finland by aeroplane or boat. The closing session will be held in Oslo on July 8. The Conference Bureau will assist those who desire to pay a visit to any holiday resort. A large number of rooms have been reserved in the smaller hotels at prices which are stated to be far below the usual Continental level. The exchange also is in favour of sterling. Further details can be obtained from the offices of the World Power Conference, 63 Lincoln's Inn Fields, London, W.C.2.

\section{Fifth Pacific Science Congress}

AT the invitation of the Government of Canada and under the auspices of the Canadian National Research Council, the Pacific Science Association will hold the fifth Pacific Science Congress, for the study of Pacific problems, in Victoria and Vancouver, B.C., Canada, on June 1-14. It is expected that some thirty countries bordering on the Pacific Ocean will be represented at the Congress by four to six hundred men of science. The president of the Executive Committee of the Congress will be Dr. H. M. Tory, president of the National Research Council of Canada and director of the National Research Laboratories. The Congress will open at Victoria on June 1, where sessions will be held until June 3. On June 4, it will proceed to Vancouver, where further sessions will be held until June 14. A postCongress tour has also been arranged from June 14 until June 19, when it will terminate at Calgary. The Congress will work in two divisions: Biological Sciences, under the chairmanship of Prof. C. McLean Fraser, professor of zoology at the University of British Columbia, Vancouver, and Physical Sciences, under the chairmanship of Prof. R. W. Brock, professor of geology and geography at the University of British Columbia. The secretary of the Congress is Mr. S. J. Cook of the National Research Council, whose address, in connexion with the Congress, is Hotel Vancouver, Vancouver, B.C., Canada.

\section{Announcements}

THE King has been pleased to appoint Sir William Cecil Dampier, fellow and sometime senior tutor of Trinity College, Cambridge, to be one of the Development Commissioners, in succession to the late $\mathrm{Mr}$. Vaughan Nash.

BY an order of the Committee of Privy Council, Sir Thomas Lewis, director of the Department of Clinical Research in University College Hospital, London, has been appointed a member of the Medical Research Council in succession to Prof. J. J. R. Macleod, regius professor of physiology in the University of Aberdeen.

THe Melchett Medal for 1933 of the Institute of Fuel has been awarded to Sir John Cadman, chairman of the Anglo-Persian Oil Co., Ltd., and the Iraq Petroleum Company. The medal is an annual award for "original research or professional, administrative, or constructive work of an outstanding character, involving the scientific preparation or use of fuel."

IN view of certain changes in the administration of the Ministry of Agriculture of Brazil, the Directoria de Meteorologia will henceforth be entitled the "Instituto de Meteorologia, Hidrometria E Ecologia Agricola". Mr. R. P. Xavier retired from the position of director of the Brazilian Meteorological Service on March 6, and has been succeeded by Mr. C. de A. Martins Costa.

IT is announced by the Paris correspondent of the Times that the French Government has created a chair of mathematical physics at the Collège de France for Prof. A. Einstein. Special legislation was necessary and a Bill was prepared by the Ministry of Education and passed rapidly through the necessary stages in the Chamber of Deputies before the Easter recess. A few days earlier, the Madrid correspondent of the Times stated that the Spanish Minister of Education had announced the acceptance by Prof. Einstein of a chair in Spain and that, while the Government had made no precise conditions, it was thought Prof. Einstein would go to Madrid.

The forty-fourth Congress of the Royal Sanitary Institute will be held at Blackpool on June 17-24, under the presidency of the Right Hon. Lord CozensHardy. The Congress will be divided into the following sections: Preventive Medicine; Architecture, Town Planning and Engineering; Maternity, Child Welfare and School Hygiene; Veterinary Hygiene ; National Health Insurance; Hygiene of Food. Conferences of representatives of sanitary authorities, medical officers of health, engineers and surveyors, sanitary inspectors and health visitors will also be held in connexion with the Congress. Particulars can be obtained from the secretary of the Institute, $\mathrm{Mr}$. J. W. Dudley Robinson, 90, Buckingham Palace Road, S.W.l.

Applications are invited for the following appointments, on or before the dates mentioned :-A junior assistant in the surgical unit of the Welsh Nationa] School of Medicine (University of Wales), The Parade, Cardiff-The Secretary (April 25). A lecturer in civil engineering and building at the Portsmouth Municipal College-The Registrar (May 5). A dairy bacteriologist in the Department of Agriculture and Horticulture of the University of Bristol-A. W. Ling, Agricultural Advisory Office, 22, Berkeley Square, Bristol 8 (May 6). An assistant lecturer in engineering at the Cardiff Technical College-The Director of Education, City Hall, Cardiff (May 6). A lecturer in electrical engineering at the Chelmsford School of Art and Technology-The Clerk to the Governors (May 8). A lecturer in pathology to dental students in the University and pathologist to the Queen's Hospital, Birmingham-The Secretary, The University, Birmingham (May 15). A demonstrator in physiology at St. Thomas's Hospital Medical School (University of London)-The Dean of the Medical School (May 27). 